\title{
Studi Kasus Mitigasi Risiko Rantai Pasok dengan Integrasi House of Risk dan Fuzzy Logic pada PT X
}

\author{
Case Study Mitigation of Supply Chain with Integration of House of Risk and Fuzzy \\ Logic at PT X
}

\author{
Ryan Rakadhitya, Natalia Hartono, Laurence \\ Jurusan Teknik Industri, Universitas Pelita Harapan, Tangerang \\ E-mail: ryanrakadhitya@yahoo.com,natalia.hartono@uph.edu, laurence.fti@uph.edu
}

\begin{abstract}
Abstrak
Manajemen rantai pasok memiliki peranan vital di dalam sebuah perusahaan. Sejak berdiri pada tahun 1997, PT.X belum memiliki pengelolaan manajemen rantai pasok yang baik sehingga masih seringkali terjadi kendala pada proses bisnis PT.X. Analisis mitigasi risiko diperlukan oleh PT.X agar dapat menanggulangi risiko yang mungkin terjadi di kemudian hari. Tujuan dilakukannya penelitian ini adalah untuk memberikan mitigasi risko dari sumber risiko prioritas yang terjadi di sepanjang proses bisnis PT.X dengan mengintegrasikan House of Risk dan Fuzzy Logic agar analisis risiko dapat dilakukan secara sistematis. Pengumpulan data dilakukan dengan cara observasi lapangan dan studi literatur sebagai penelitian pendahuluan, setelah itu penulis juga melakukan wawancara, brainstorming serta menyebarkan kuesioner kepada internal perusahaan. Kuesioner yang dibagikan menjadi dasar dalam pengolahan data menggunakan House of Risk yang diintegrasikan dengan Fuzzy Logic. Setelah data diolah, terdapat 10 sumber risiko yang akan diberikan aksi mitigasi, tetapi atas permintaan perusahaan, 5 sumber risiko dominan yang akan diprioritaskan untuk diberi aksi mitigasi. Dari 5 sumber risiko yang telah diprioritaskan, terdapat 7 aksi mitigasi dalam menanggulangi 5 sumber risiko dominan pada proses bisnis perusahaan.
\end{abstract}

Kata Kunci: Manajemen rantai pasok, House of Risk, Fuzzy Logic

\begin{abstract}
Supply chain management has a vital role in a company. Since its establishment in 1997, PT. X has not practice a good supply chain management, so there were obstacles in their business process. Risk mitigation analysis is needed by PT.X in order to cope with risks that might occur in the future. The purpose of this research is to provide risk mitigation from priority risk sources that occur throughout the PT.X business process by integrating House of Risk and Fuzzy Logic to give systematic analysis. Data collection was carried out using observations and literature studies as preliminary research. Then the next steps were conducted interviews, brainstorming and distributing questionnaires to the company. Questionnaires were distributed as a basis for data processing using the House of Risk which is integrated with Fuzzy Logic. After the data is processed, there are 10 sources of risk that will be given mitigation action. However, only 5 dominant sources of risk will be prioritized to be given mitigation action as the request from the company. Of the 5 priority sources of risk, there are 7 mitigation actions in tackling 5 dominant sources of risk in the company's business processes.
\end{abstract}

Keywords: Supply Chain Management, House of Risk, Fuzzy Logic

\section{Pendahuluan}

Pada zaman globalisasi seperti sekarang ini, untuk meningkatkan daya saing dan efisiensi maupun efektifitas bagi perusahaan, integrasi antara pemasok dan perusahaan mempunyai peran yang penting. Oleh karena itu, manajemen rantai pasok dibutuhkan oleh setiap perusahaan terutama bagi perusahaan manufaktur. Rantai pasok memiliki peranan vital didalam proses bisnis sebuah perusahaan yang melingkupi permintaan bahan baku kepada supplier sampai kepada pemenuhan permintaan konsumen. Di dalam setiap aktivitas operasional rantai pasok, besar kemungkinan akan 
muncul risiko. Menurut Render dan Heizer (2014) terdapat beberapa kategori risiko, diantaranya adalah kegagalan kualitas pemasok, keterlambatan dan kerusakan logistik, pencurian, perusakan dan terorisme. Risiko tersebut merupakan faktor-faktor yang dapat menghambat aktivitas rantai pasok di sebuah perusahaan.

PT $\mathrm{X}$ adalah perusahaan yang membuat wiring harness yang memiliki pembeli utama yang membeli secara tetap. Pembeli akan membuat ramalan pemesanan barang ke PT X untuk beberapa waktu ke depan. Kesulitan yang dihadapi PT X adalah pembeli seringkali menurunkan maupun menambahkan jumlah pembelian yang tidak sesuai dengan ramalan pemesanan yang telah diberikan kepada PT X. Penambahan permintaan seringkali mendadak dan PT X harus menyanggupi permintaan tambahan karena pembeli utama ini merupakan pembeli tetap yang memiliki porsi sangat besar bagi kelangsungan perusahaan. Selain itu dari hasil wawancara, terdapat masalah internal pada PT X yaitu kendala pada mesin dan pengendalian kualitas yang saat ini masih belum berjalan dengan baik.

Sebagai usaha untuk mengatasi permasalahan dalam rantai pasok di PT X diperlukan identifikasi dan penanganan agar perusahaan dapat melayani pembeli dengan baik. Model dalam analisa mitigasi risiko pada rantai pasok yang paling banyak dirujuk dan memberikan laporan hasil yang baik adalah model House of Risk (HOR) yang dilakukan ole Pujawan dan Geraldine (2009). Model ini adalah pengembangan dari House of Risk (HOR) dan Failure Mode and Effect Analysis (FMEA). HOR memiliki dua fase, yaitu fase identifikasi risiko (risk identification) dan fase penanganan risiko (risk treatment). Dengan menggunakan model HOR, diharapkan akan memberikan manfaat untuk PT X dalam mengetahui risiko yang kemungkinan terjadi pada aliran rantai pasok dan dapat mengetahui langkah-langkah penanganan risiko yang terjadi. PT X sampai saat ini belum pernah melakukan sistem pengelolaan rantai pasok sehingga sumber risiko belum diketahui. Akibatnya adalah mitigasi risiko yang tepat belum dapat dilakukan oleh PT X.

Pengambilan data pada HOR menggunakan kuesioner dengan menggunakan skala Likert. Pengisian kuesioner dapat subjektif dan berbeda antara tiap responden. Ma dan Wong (2018) mengusulkan penggunaan fuzzy pada HOR untuk membuat para pengambil kebijakan dapat menganalisa secara sistematis potensi risiko di perusahaan manufaktur. Tujuan dalam penelitian ini adalah melakukan studi kasus mitigasi risiko manajemen rantai pasok menggunakan integrasi House of Risk dan Fuzzy Logic pada PT X. Pengambilan data dilakukan dari bulan Januari hingga bulan Mei 2019.

\section{Tinjauan Pustaka}

Dibawah ini akan dijelaskan mengenai manajemen rantai pasok, ruang lingkup manajemen rantai pasok, risiko, manajemen risiko, supply chain operations reference (SCOR), FMEA, fuzzy logic, House of Risk (HOR).

\subsection{Manajemen rantai pasok}

Levi, et.al. (2000) mendefinisikan manajemen rantai pasok sebagai suatu metode yang digunakan untuk mencapai pengintegrasian yang efisien dari pemasok, pabrikan, distributor, pengecer dan pelanggan. Artinya barang yang akan diproduksi memiliki jumlah yang tepat sesuai dengan permintaan, dalam waktu yang tepat, dan pada tempat yang tepat dengan satu tujuan untuk mencapai biaya yang minimum serta mencapai kepuasan pelayanan yang diinginkan. Pujawan dan Mahendrawati (2010), menjelaskan bahwa semua pihak mulai dari pemasok, pabrikan, distributor, pengecer, dan pelanggan memiliki peran yang penting untuk menciptakan produk dengan kualitas tinggi serta ekonomis. Hal ini yang menjadi dasar terlahirnya konsep baru yaitu Manajemen rantai pasok.

Di dalam buku yang berjudul Supply Chain Management edisi ke-3, Pujawan dan Mahendrawati (2017) juga mengatakan bahwa terdapat 3 macam aliran yang biasa terdapat dalam sistem suatu rantai pasok. Jenis aliran yang pertama yaitu aliran material yang mengalir dari pemasok sampai kepada konsumen. Kedua, merupakan aliran yang berkaitan dengan keuangan mencakup kredit, jadwal pembayaran dan sebagainya yang terjadi di sepanjang hulu ke lihir dan sebaliknya. Dan 
yang ketiga, merupakan aliran informasi yang berkaitan dengan forecast, demand dan sebagainya yang mengalir dari pemasok sampai kepada konsumen sebaliknya. Aliran informasi berperan sangat vital dalam menciptakan rantai pasok yang unggul.

\subsection{Risiko}

Kamus Besar Bahasa Indonesia (KBBI), mendefinisikan risiko sebagai akibat yang kurang menyenangkan dan dapat merugikan. Risiko selalu berbicara tentang adanya kemungkinan yang dapat menimbulkan kerugian yang tidak diinginkan.

\subsection{Fuzzy Logic}

Logika Fuzzy dikenalkan pertama kali oleh Prof. Lotti A. Zadeh pada tahun 1965. Secara umum, logika fuzzy dapat diartikan sebagai logika kabur yang mempunyai unsur ketidakpastian. Unsur ketidakpastian dapat kita jumpai dalam kotak hitam yang terdapat pada saat kita memetakan suatu ruang input ke dalam suatu ruang output dengan didasari oleh konsep himpunan Fuzzy. Menurut Sri Kusumadewi (2010), terdapat beberapa kelebihan dalam menggunakan logika fuzzy, antara lain:

1. Logika fuzzy merupakan sebuah ide matematis yang mendasari penalaran fuzzy sebagai sesuatu yang mudah dimengerti dan mudah untuk diaplikasikan.

2. Logika fuzzy sangatlah adaptif yang artinya dapat diintegrasikan dengan metode lain.

3. Logika fuzzy memiliki toleransi terhadap data-data yang tidak valid.

4. Logika fuzzy dapat memodelkan fungsi-fungsi non-linier yang amat rumit.

5. Logika fuzzy dapat membangun dan mengaplikasikan pengalaman- pengalaman para pakar secara langsung dengan bantuan software.

6. Logika fuzzy dapat diintegrasikan dengan teknik-teknik kendali secara konservatif.

7. Logika fuzzy didasarkan pada bahasa alamiah.

\subsection{House of Risk (HOR)}

Model House of Risk (HOR) diperkenalkan oleh Pujawan dan Geraldin (2009) merupakan sebuah gabungan antara House of Quality (HOQ) dan Failure Mode \& Effect Analysis (FMEA). Model HOR dibagi menjadi dua fase, kedua fase tersebut antara lain:

1. HOR Fase Pertama

Fase pertama dalam HOR merupakan fase dimana dilakukannya identifikasi risiko. Fase ini dilakukan untuk mengetahui agen risiko dan sumber risiko yang diprioritaskan untuk dilakukan tindakan mitigasi. Tahapan pada HOR fase pertama sebagai berikut:

1) Melakukan identifikasi kegiatan dalam rantai pasok berdasarkan model SCOR.

2) Mengidentifikasi kejadian risiko yang terdapat pada kegiatan rantai pasok.

3) Menentukan risk event serta menentukan seberapa besar dampak yang akan timbul yang akan mempengaruhi system rantai pasok perusahaan serta menentukan nilai severity berdasarkan pada tabel skala severity. Nilai severity memiliki skala 1-10 dimana skala 1 merupakan kejadian dimana tidak memiliki efek pada sistem, sedangkan 10 menandakan kejadian risiko memiliki dampak yang sangat berbahaya.

4) Menentukan risk agent serta menentukan kemungkinan terjadinya (occurance) sumber risiko berdasarkan skala occurance. Nilai occurance memiliki skala 1-10 dimana skala 1 merupakan kejadian dimana tidak pernah terjadi, sedangkan 10 menandakan sumber risiko sangat sering terjadi dalam sistem.

5) Menentukan hubungan antara agen risiko dan sumber risiko. Pembobotan nilai korelasi antara risk event dan risk agent dengan skala nilai korelasi:

Tabel 1. Nilai Korelasi antara Risk Event dan Risk Agent

\begin{tabular}{|l|l|}
\hline Ranking & Correlation \\
\hline 0 & Tidak ada hubungan \\
\hline 1 & Hubungan lemah \\
\hline 3 & Hubungan sedang \\
\hline 9 & Hubungan kuat \\
\hline
\end{tabular}

Sumber: Pujawan dan Geraldin, 2009 
6) Setelah data yang dikumpulkan telah lengkap, dilakukan perhitungan nilai ARP dengan sebagai berikut:

$A R P_{j}=O_{j} \sum S_{i} R_{i j}$

Keterangan :

ARP : $\quad$ Nilai Agregat Potensial Risiko

$\mathrm{O}_{\mathrm{j}} \quad$ : $\quad$ Nilai Occurrence Agen Risiko

$\mathrm{S}_{\mathrm{i}} \quad$ : $\quad$ Nilai Severity Kejadian Risiko

$\mathrm{R}_{\mathrm{ij}} \quad$ : $\quad$ Hubungan Antara Agen Risiko dan Kejadian Risiko

Tahapan selanjutnya adalah memasukan angka tersebut pada tabel HOR Fase Pertama seperti pada Tabel 2.

Tabel 2. HOR fase 1

\begin{tabular}{|c|c|c|c|c|c|c|c|c|c|}
\hline \multirow[t]{2}{*}{ Business Processes } & \multirow{2}{*}{$\begin{array}{l}\text { Risk Event } \\
\text { (Ei) }\end{array}$} & \multicolumn{7}{|c|}{ Risk Agents (Aj) } & \multirow{2}{*}{$\begin{array}{l}\text { Severity of } \\
\text { Risk event i } \\
\text { (Si) }\end{array}$} \\
\hline & & $A_{1}$ & A2 & A3 & A4 & A5 & A6 & A7 & \\
\hline \multirow[t]{2}{*}{ Plan } & $E_{1}$ & R11 & R12 & R13 & & & & & S1 \\
\hline & $\mathrm{E}_{2}$ & & & & & & & & $\mathrm{~S} 2$ \\
\hline \multirow[t]{2}{*}{ Source } & $E_{3}$ & R21 & $\mathrm{R} 22$ & & & & & & S3 \\
\hline & $\mathrm{E}_{4}$ & & & & & & & & S4 \\
\hline \multirow[t]{2}{*}{ Make } & $\mathrm{E}_{5}$ & R31 & & & & & & & S5 \\
\hline & $\mathrm{E}_{6}$ & & & & & & & & S6 \\
\hline \multirow[t]{2}{*}{ Deliver } & $\mathrm{E}_{7}$ & & & & & & & & S7 \\
\hline & $\mathrm{E}_{8}$ & & & & & & & & S8 \\
\hline Return & $\mathrm{E}_{9}$ & & & & & & & & \$9 \\
\hline \multirow{3}{*}{$\begin{array}{l}\text { Occurrence of Agent } j \\
\text { Aggregate Risk Potential } j\end{array}$} & & $\mathrm{O} 1$ & $\mathrm{O} 2$ & $\mathrm{O} 3$ & $\mathrm{O} 4$ & O5 & O6 & 07 & \\
\hline & & AR & $\mathrm{AR}$ & AR & AR & ARP & ARP & ARP & \\
\hline & & P1 & $\mathrm{P} 2$ & P3 & P4 & 5 & 6 & 7 & \\
\hline Priority rank of agent $j$ & & & & & & & & & \\
\hline
\end{tabular}

Sumber: Pujawan dan Geraldin, 2009

2. HOR Fase Kedua

Fase kedua dalam HOR digunakan untuk menentukan beberapa tindakan yang efektif dalam mengurangi terjadinya sumber risiko. Data dari HOR fase 1 digunakan di HOR fase 2. Agen risiko diurutkan dan dipilih berdasarkan nilai ARP yang paling tinggi yang dapat dilihat pada Tabel 3.

Tabel 3. HOR fase 2

\begin{tabular}{|c|c|c|c|c|c|c|}
\hline \multirow{2}{*}{ To be Treated Risk Agent $\left(A_{j}\right)$} & \multicolumn{5}{|c|}{ Preventive Action $\left(P_{k}\right)$} & \multirow{2}{*}{$\begin{array}{c}\text { Aggregate Risk } \\
\text { Potentials } \\
\left(\mathrm{ARP}_{\mathrm{i}}\right) \\
\end{array}$} \\
\hline & $\mathbf{P A}_{1}$ & $\mathrm{PA}_{2}$ & $\mathbf{P A}_{3}$ & $\mathrm{PA}_{4}$ & $\mathrm{PA}_{5}$ & \\
\hline $\mathrm{A}_{1}$ & $\mathrm{E}_{11}$ & & & & & $\mathrm{ARP}_{1}$ \\
\hline $\mathrm{A}_{2}$ & & & & & & $\mathrm{ARP}_{2}$ \\
\hline $\mathrm{A}_{3}$ & & & & & & $\mathrm{ARP}_{3}$ \\
\hline $\mathrm{A}_{4}$ & & & & & & $\mathrm{ARP}_{4}$ \\
\hline Total effectiveness of action $k$ & $\mathrm{TE}_{1}$ & $\mathrm{TE}_{2}$ & $\mathrm{TE}_{3}$ & $\mathrm{TE}_{4}$ & $\mathrm{TE}_{5}$ & \\
\hline $\begin{array}{l}\text { Degree of difficulty performing } \\
\text { action } k\end{array}$ & $\mathrm{D}_{1}$ & $\mathrm{D}_{2}$ & & $\mathrm{D}_{4}$ & $\mathrm{D}_{5}$ & \\
\hline Effectiveness to difficulty ratio & $\mathrm{ETD}_{1}$ & $\mathrm{ETD}_{2}$ & $\mathrm{ETD}_{3}$ & $\mathrm{ETD}_{4}$ & $\mathrm{ETD}_{5}$ & \\
\hline Rank of priority & $\mathrm{R}_{1}$ & $\mathrm{R}_{2}$ & $\mathrm{R}_{3}$ & $\mathrm{R}_{4}$ & $\mathrm{R}_{5}$ & \\
\hline
\end{tabular}

Sumber : Pujawan dan Geraldin, 2009

Tahapan pada HOR fase 2 sebagai berikut:

1. Mengidentifikasi tindakan-tindakan efektif yang dapat mencegah terjadinya agen risiko.

2. Menenetukan hubungan kolerasi antara tindakan pencegahan dengan agen risiko berdaraskan tabel nilai korelasi antara risk event dan risk agent.

3. Menghitung nilai total efektivitas dari setiap tindakan pencegahan dengan rumus:

$\mathrm{TE}_{\mathrm{k}}=\sum_{\mathrm{j}} \mathrm{ARP}_{\mathrm{j}} \mathrm{E}_{\mathrm{jk}}$

Keterangan :

$\mathrm{TE}_{\mathrm{k}} \quad$ :Total efektivitas tindak pencegahan

$\mathrm{E}_{\mathrm{jk}} \quad$ :Hubungan antara tindak pencegahan dan agen risiko 
4. Memperkirakan tingkat kesulitan di dalam melakukan masing-masing tindakan pencegahan, dengan nilai sebagai berikut:

Tabel 4. Tingkat Kesulitan

\begin{tabular}{|l|l|}
\hline \multicolumn{1}{|c|}{ Nilai } & \multicolumn{1}{c|}{ Deskripsi } \\
\hline 3 & Mudah untuk diterapkan \\
\hline 4 & Agak sulit untuk diterapkan \\
\hline 5 & Sulit untuk diterapkan \\
\hline
\end{tabular}

Menghitung nilai total efektivitas rasio kesulitan dengan rumus ETDk $=$ TEk/Dk dimana Dk merupakan derajat kesulitan pada setiap tindakan pencegahan risiko.

5. Melakukan ranking prioritas dari masing-masing tindakan pencegahan ( $\mathrm{Rk})$ dimana urutan pertama untuk aksi tindakan pencegahan dengan nilai ETDk tertinggi.

\section{Metodologi Penelitian}

Berikut ini merupakan penjelasan mengenai langkah-langkah penelitian yang dilakukan di PT X dan dapat dilihat pada gambar 3.1.

1. Melakukan penelitian pendahuluan untuk mengetahui secara garis besar proses bisnis dan kendala yang sering ditemukan pada aktivitas rantai pasok PT X.

2. Penentuan perumusan masalah yaitu PT $X$ belum pernah mengukur kinerja rantai pasok yang dimiliki oleh perusahaan sehingga analisis mitigasi risiko yang tepat belum dapat dilakukan.

3. Penentuan tujuan penelitian agar peneliti memiliki pedoman yang lebih jelas dalam melakukan penelitian.

4. Melakukan studi literatur untuk mencari tahu hal-hal yang berkaitan dengan topik pembahasan melalui buku dan jurnal yang akan digunakan sebagai acuan oleh penulis.

5. Melakukan pengumpulan data dengan beberapa teknik, antara lain: kajian literatur, observasi, wawancara, brainstorming dan kuesioner.

6. Melakukan pengolahan data dengan menggunakan HOR yang di integrasikan dengan fuzzy logic. Berikut merupakan tahapan dalam pengolahan data:

1) Tahapan awal, penulis melakukan pemetaan aktivitas rantai pasok menggunakan SCOR yang di dalamnya terdapat plan, source, make, delivery, return.

2) Setelah itu, penulis melakukan wawancara dengan bagian eksekutif untuk mengidentifikasi risk event dan risk agent dalam kerangka SCOR yang terjadi sepanjang proses rantai pasok.

3) Setelah melakukan wawancara, peneliti melakukan brainstorming dengan bagian eksekutif dalam menyusun kuesioner yang akan digunakan sebagai nilai input dan output dari metode fuzzy logic yang akan diolah dengan bantuan software MATLAB 2019.

4) Setelah nilai input dan output ditentukan, langkah selanjutnya akan dilakukan proses Fuzzy.

5) Setelah proses fuzzy dilakukan dan nilai pembobotan untuk risk event dan risk agent telah didapatkan, langkah selanjutnya akan dilakukan pengolahan data lebih lanjut menggunakan metode House of Risk fase 2.

7. Melakukan pembahasan dari data yang telah diolah.

8. Membuat kesimpulan dan saran dari hasil pembahasan yang dilakukan. 


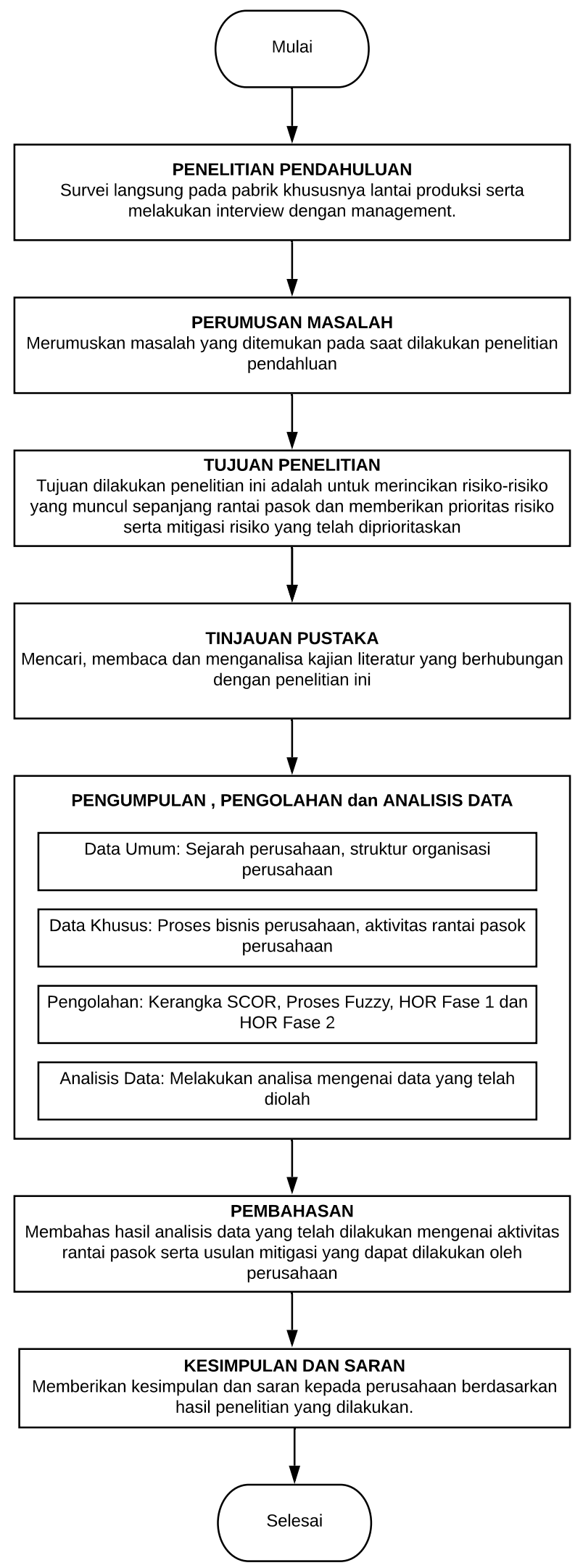

Gambar 1. Metode Alir Penelitian 


\section{Pembahasan}

Bagian ini berisi mengenai pengumpulan \& pengolahan data serta pembahasan dari data yang telah diolah.

\subsection{Pengumpulan Data}

Pada tahap pertama, dilakukan pemetaan aktivitas rantai pasok di PT X dengan cara melakukan brainstorming dengan eksekutif perusahaan menggunakan pendekatan Supply Chain Operations Reference (SCOR). Di dalam kerangka SCOR, terdapat 5 proses bisnis yang terdapat dalam proses rantai pasok. Kelima proses bisnis tersebut ialah plan, source, make, delivery, dan return. Pembagian proses bisnis ini bertujuan untuk mengetahui dimana risiko tersebut dapat terjadi.

Tabel 5. Daftar Risk Event

\begin{tabular}{|c|l|l|}
\hline Kode & \multicolumn{1}{|c|}{ Risk Event } & Proses \\
\hline E1 & Pemintaan tidak sesuai dengan forecast & Plan \\
\hline E2 & $\begin{array}{l}\text { Terjadi kekurangan material yang disebabkan oleh kesalahan } \\
\text { perhitungan }\end{array}$ & Plan \\
\hline E3 & Pengadaan material terlambat & Plan \\
\hline E4 & Pengiriman material dari supplier mengalami keterlambatan & Source \\
\hline E5 & Bahan mentah yang diterima tidak sesuai dengan spesifikasi & Source \\
\hline E6 & Keterlambatan memproduksi barang dari jadwal & Make \\
\hline E7 & Target produksi tidak tercapai & Make \\
\hline E8 & Keterlambatan pengiriman barang jadi ke customer & Delivery \\
\hline E9 & Barang jadi yang dikirim tidak sesuai dengan spesifikasi & Delivery \\
\hline E10 & Retur barang jadi dari customer & Return \\
\hline E11 & Retur bahan baku ke supplier & Return \\
\hline
\end{tabular}

Tabel 6. Tabel Risk Agent

\begin{tabular}{|c|l|}
\hline Kode & \multicolumn{1}{|c|}{ Risk Agent } \\
\hline A1 & Kesalahan forecast dari customer \\
\hline A2 & Purchase order secara mendadak oleh customer \\
\hline A3 & Komunikasi kurang baik dengan supplier \\
\hline A4 & Kapasitas produksi tidak memadai \\
\hline A5 & Terlambat dalam memenuhi target produksi \\
\hline A6 & Terjadi kerusakan atau kendala pada mesin \\
\hline A7 & Kinerja buruh tidak maksimal \\
\hline A8 & Terjadi cacat produk pada hasil produksi \\
\hline A9 & Human error \\
\hline A10 & Kesalahan pada divisi pengiriman \\
\hline
\end{tabular}

Setelah pemetaan aktivitas rantai pasok telah dilakukan dan diperoleh data risk event dan risk agent melalui hasil wawancara dengan bagian eksekutif perusahaan, kemudian selanjutnya dilakukan brainstorming dengan bagian eksekutif perusahaan untuk membuat kuesioner sebagai nilai input untuk pengolahan fuzzy logic.

Terdapat 11 rancangan kuesioner untuk risk event, berikut merupakan dua contoh diantara rancangan tersebut:

1. Permintaan tidak sesuai dengan forecast berdampak pada:

a) Perubahan schedule produksi 
b) Kapasitas produksi terganggu

c) Kerugian finansial

2. Terjadi kekurangan material yang disebabkan kesalahan perhitungan berdampak pada:

a) Citra perusahaan menurun

b) Operasional produksi terganggu

c) Keterlambatan pengiriman barang jadi ke konsumen

Terdapat 10 rancangan kuesioner untuk risk agent, berikut merupakan dua contoh diantara rancangan tersebut:

1. Kesalahan forecast disebabkan oleh:

a) Permintaan pasar fluktuatif

b) Informasi perkembangan trend konsumen tidak akurat

2. Purchase order secara mendadak oleh customer disebabkan oleh:

a) Permintaan pasar fluktuatif (yang cenderung bertambah)

b) Desakan permintaan dari pihak customer

\subsection{Proses Fuzzy}

Pengolahan fuzzy ini dilakukan dengan bantuan software MATLAB 2019. Berikut merupakan langkah-langkah dalam mengolah fuzzy:

\subsubsection{Pembentukan variable, semesta pembicaraan serta himpunan fuzzy}

Langkah pertama yang dilakukan dalam pengolahan data adalah menentukan variabel, nama himpunan fuzzy serta semesta pembicaraan yang akan digunakan. Tabel 7 adalah input untuk risk event dan tabel 8 adalah input untuk risk agent.

Tabel 7. Penentuan variabel, himpunan fuzzy dan semesta pembicaraan untuk risk event

\begin{tabular}{|c|c|c|c|c|}
\hline \multicolumn{5}{|c|}{ Risk Event } \\
\hline Fungsi & Nama Variabel & Nama Himpunan Fuzzy & $\begin{array}{c}\text { Semesta } \\
\text { Pembicaraan }\end{array}$ & Domain Unit \\
\hline \multirow{15}{*}{ Input } & \multirow{5}{*}{$\begin{array}{l}\text { Perubahan jadwal } \\
\text { produksi }\end{array}$} & $\begin{array}{l}\text { Sangat Tidak } \\
\text { Berpengaruh }\end{array}$ & \multirow[t]{5}{*}[0-5]{} & {$\left[\begin{array}{lllllll}-0,5 & 0 & 1 & 1,5\end{array}\right]$} \\
\hline & & Tidak Berpengaruh & & {$\left[\begin{array}{llll}1 & 1,5 & 2 & 2,5\end{array}\right]$} \\
\hline & & Netral & & $\begin{array}{c}{[1,752,252,75} \\
3,25]\end{array}$ \\
\hline & & Berpengaruh & & {$\left[\begin{array}{llll}2,5 & 3 & 3,5 & 4\end{array}\right]$} \\
\hline & & Sangat Berpengaruh & & {$[3,5 \quad 4 \quad 5 \quad 5,5]$} \\
\hline & \multirow{5}{*}{$\begin{array}{l}\text { Kapasitas produksi } \\
\text { terganggu }\end{array}$} & $\begin{array}{l}\text { Sangat Tidak } \\
\text { Berpengaruh }\end{array}$ & \multirow[t]{5}{*}{ [0-5] } & {$\left[\begin{array}{lllllll}-0,5 & 0 & 1 & 1,5]\end{array}\right.$} \\
\hline & & Tidak Berpengaruh & & {$\left[\begin{array}{llll}1 & 1,5 & 2 & 2,5\end{array}\right]$} \\
\hline & & Netral & & $\begin{array}{c}{[1,752,252,75} \\
3,25]\end{array}$ \\
\hline & & Berpengaruh & & {$\left[\begin{array}{lllll}2,5 & 3 & 3,5 & 4\end{array}\right]$} \\
\hline & & Sangat Berpengaruh & & {$[3,5 \quad 4 \quad 5 \quad 5,5]$} \\
\hline & \multirow{5}{*}{ Kerugian finansial } & $\begin{array}{l}\text { Sangat Tidak } \\
\text { Berpengaruh }\end{array}$ & \multirow[t]{5}{*}[0-5]{} & {$\left[\begin{array}{lllllll}-0,5 & 0 & 1 & 1,5\end{array}\right]$} \\
\hline & & Tidak Berpengaruh & & {$\left[\begin{array}{llll}1 & 1,5 & 2 & 2,5\end{array}\right]$} \\
\hline & & Netral & & $\begin{array}{c}{[1,752,252,75} \\
3,25]\end{array}$ \\
\hline & & Berpengaruh & & {$\left[\begin{array}{llllll}2,5 & 3 & 3,5 & 4\end{array}\right]$} \\
\hline & & Sangat Berpengaruh & & {$[3,5 \quad 4 \quad 5 \quad 5,5]$} \\
\hline \multirow{5}{*}{ Output } & \multirow{5}{*}{$\begin{array}{l}\text { Pesanan yang diterima } \\
\text { tidak sesuai dengan } \\
\text { forecast }\end{array}$} & Tidak Ada Dampak & \multirow[t]{5}{*}{ [0-10] } & {$\left[\begin{array}{llll}-1 & 0 & 2 & 3\end{array}\right]$} \\
\hline & & Sedikit Berdampak & & {$[23,55]$} \\
\hline & & Sedang & & {$[3,556,5]$} \\
\hline & & Bahaya & & {$\left[\begin{array}{lll}5 & 65 & 8\end{array}\right]$} \\
\hline & & Sangat Bahaya & & $\left.\begin{array}{llllll}7 & 8 & 10 & 13\end{array}\right]$ \\
\hline
\end{tabular}


STUDI KASUS MITIGASI RISIKO RANTAI PASOK (Ryan R., dkk.)

Tabel 8. Penentuan variabel, himpunan fuzzy dan semesta pembicaraan untuk risk agent

\begin{tabular}{|c|c|c|c|c|}
\hline \multicolumn{5}{|c|}{ Risk Agent } \\
\hline Fungsi & Nama Variabel & Nama Himpunan Fuzzy & $\begin{array}{c}\text { Semesta } \\
\text { Pembicaraan }\end{array}$ & Domain Unit \\
\hline \multirow{10}{*}{ Input } & \multirow{5}{*}{$\begin{array}{l}\text { Permintaan pasar } \\
\text { fluktuatif }\end{array}$} & Sangat Tidak Berpengaruh & \multirow[t]{5}{*}[0-5]{} & {$\left[\begin{array}{lllll}-0,5 & 0 & 1 & 1,5\end{array}\right]$} \\
\hline & & Tidak Berpengaruh & & {$\left[\begin{array}{llll}1 & 1,5 & 2 & 2,5\end{array}\right]$} \\
\hline & & Netral & & 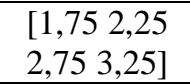 \\
\hline & & Berpengaruh & & {$\left[\begin{array}{lllll}2,5 & 3 & 3,5 & 4\end{array}\right]$} \\
\hline & & Sangat Berpengaruh & & {$\left[\begin{array}{llll}3,5 & 4 & 5 & 5,5]\end{array}\right.$} \\
\hline & \multirow{5}{*}{$\begin{array}{l}\text { Terbatasnya } \\
\text { informasi } \\
\text { perkembangan } \\
\text { trend konsumen }\end{array}$} & Sangat Tidak Berpengaruh & \multirow[t]{5}{*}[0-5]{} & {$\left[\begin{array}{llll}-0,5 & 0 & 1 & 1,5\end{array}\right]$} \\
\hline & & Tidak Berpengaruh & & {$\left[\begin{array}{llll}1 & 1,5 & 2 & 2,5\end{array}\right]$} \\
\hline & & Netral & & $\begin{array}{l}{\left[\begin{array}{ll}1,75 & 2,25 \\
2,75 & 3,25]\end{array}\right.}\end{array}$ \\
\hline & & Berpengaruh & & {$\left[\begin{array}{lllll}2,5 & 3 & 3,5 & 4\end{array}\right]$} \\
\hline & & Sangat Berpengaruh & & {$[3,5455,5]$} \\
\hline \multirow{5}{*}{ Output } & \multirow{5}{*}{$\begin{array}{l}\text { Kesalahan forecast } \\
\text { dari pembeli }\end{array}$} & Hampir Tidak Pernah & \multirow[t]{5}{*}[0-10]{} & {$\left[\begin{array}{llll}-1 & 0 & 2 & 3\end{array}\right]$} \\
\hline & & Jarang & & {$\left[\begin{array}{llll}2 & 3,5 & 5\end{array}\right]$} \\
\hline & & Sedang & & {$[3,5$ 5 6,5$]$} \\
\hline & & Tinggi & & {$\left[\begin{array}{llll}5 & 6,5 & 8\end{array}\right]$} \\
\hline & & Sangat Tinggi & & {$\left[\begin{array}{llll}7 & 8 & 10 & 13\end{array}\right]$} \\
\hline
\end{tabular}

\subsubsection{Pembentukan Fungsi Keanggotaan}

Setelah variabel, nama himpunan fuzzy serta semesta pembicaraan telah ditetapkan, langkah selanjutnya adalah membuat fungsi keanggotaan untuk tiap variabel. Pembentukan fungsi keanggotaan dibantu dengan menggunakan software MATLAB 2019. Berikut merupakan fungsi keanggotaan untuk risk event dan risk agent.

- Fungsi keanggotan untuk risk event

Input

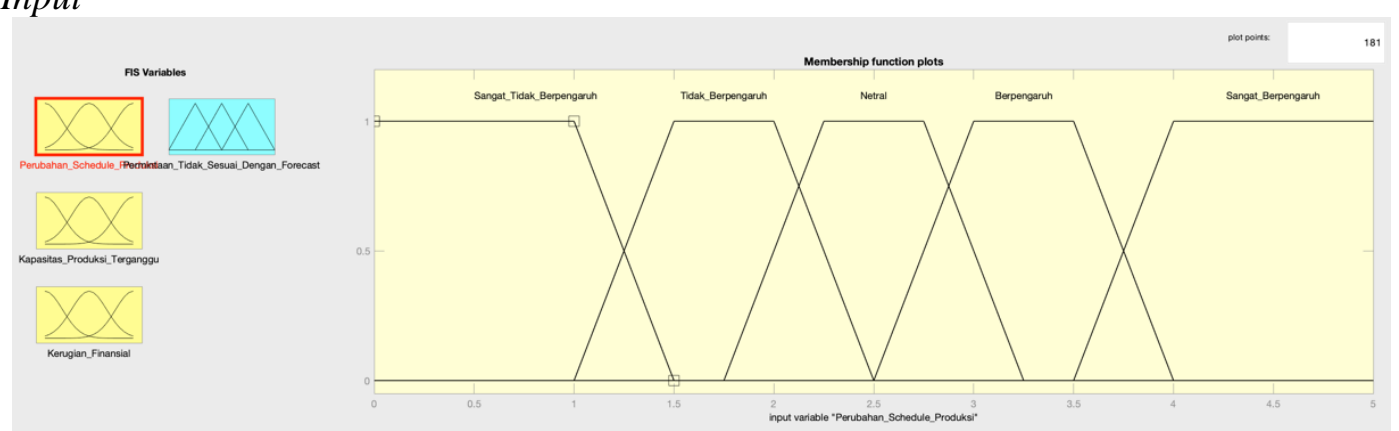

Gambar 2. Input variabel perubahan jadwal produksi

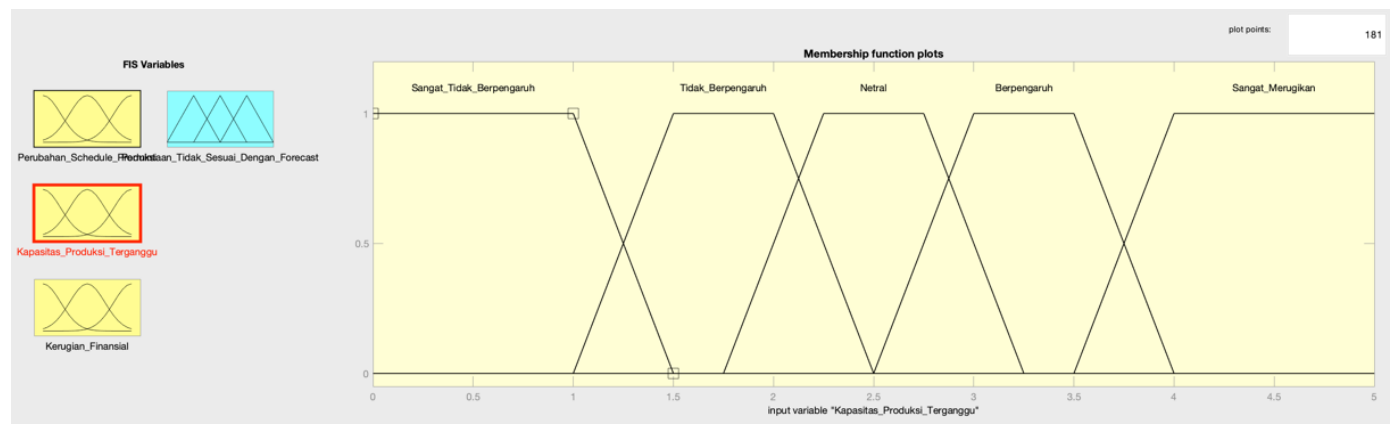

Gambar 3. Input variabel kapasitas produksi terganggu 


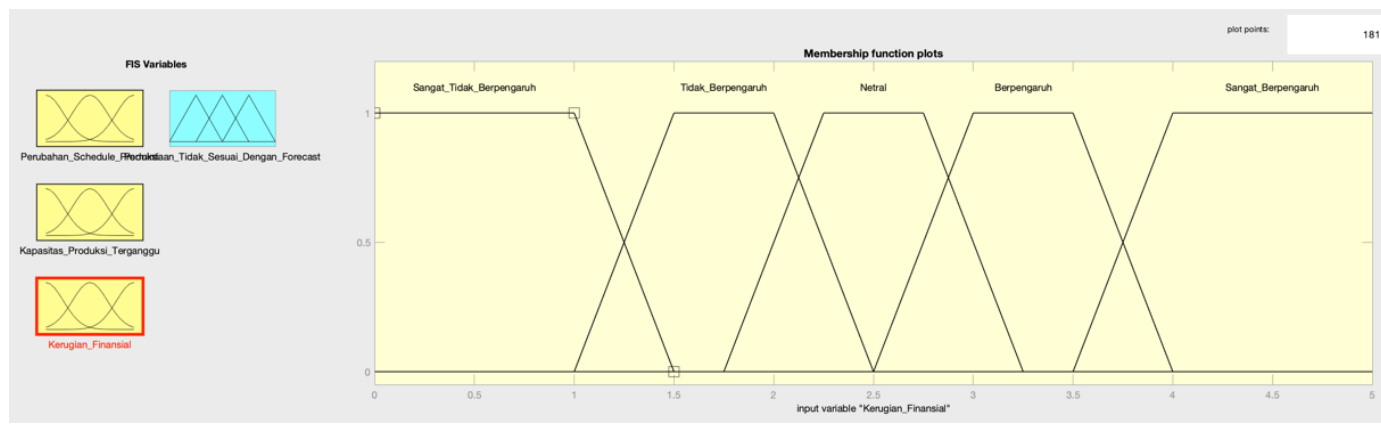

Gambar 4. Input variabel kerugian finansial

\section{Output}
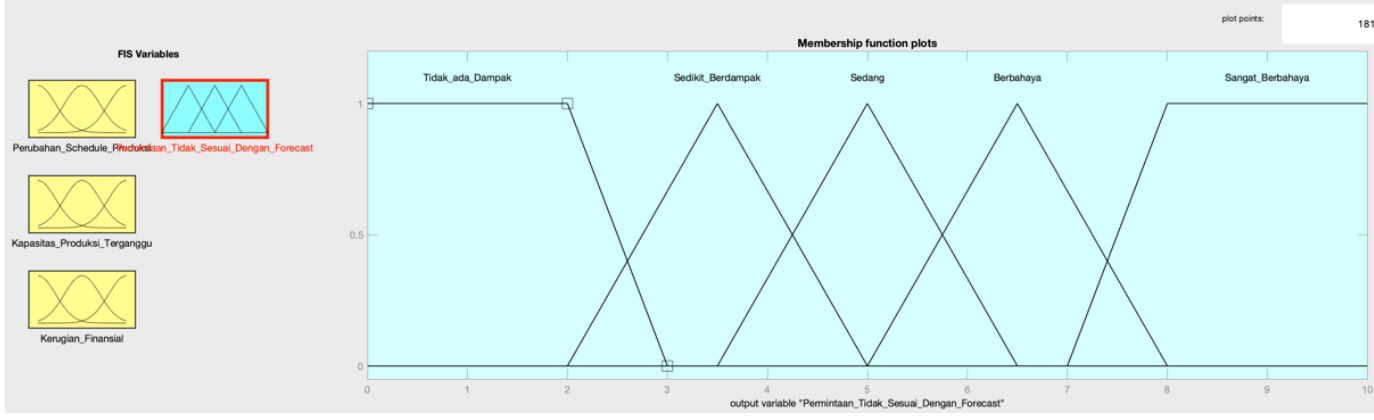

Gambar 5. Output variabel pesanan yang diterima tidak sesuai dengan forecast

- Fungsi keanggotan untuk risk agent

Input:
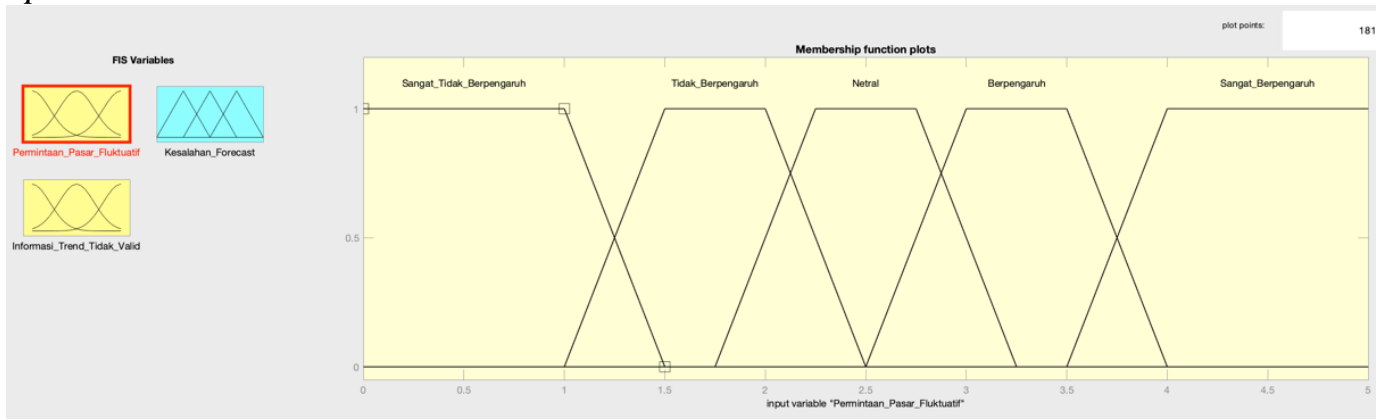

Gambar 6. Input variabel permintaan pasar fluktuatif

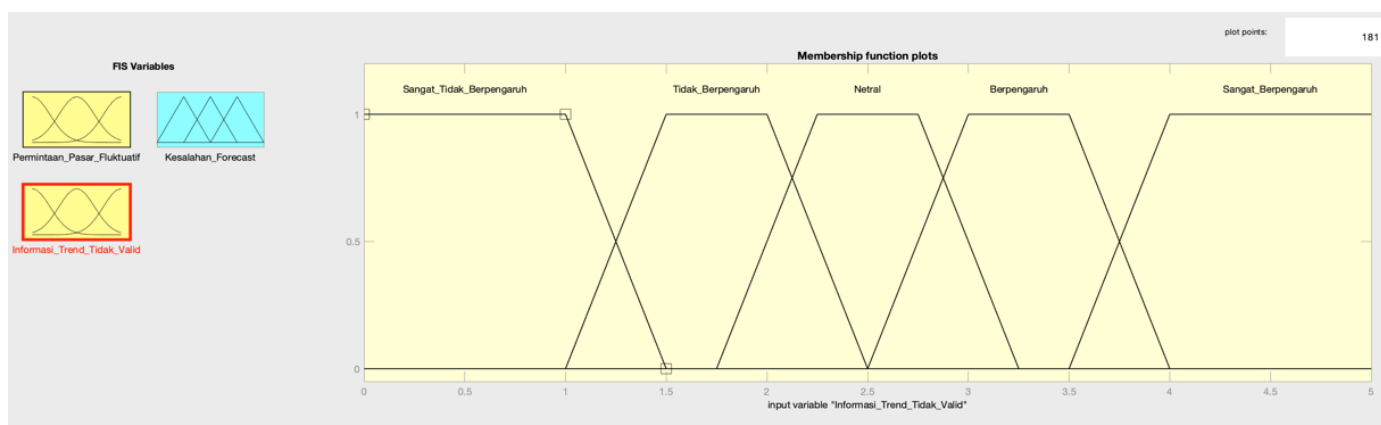

Gambar 7. Input variabel informasi trend tidak valid 
Output:

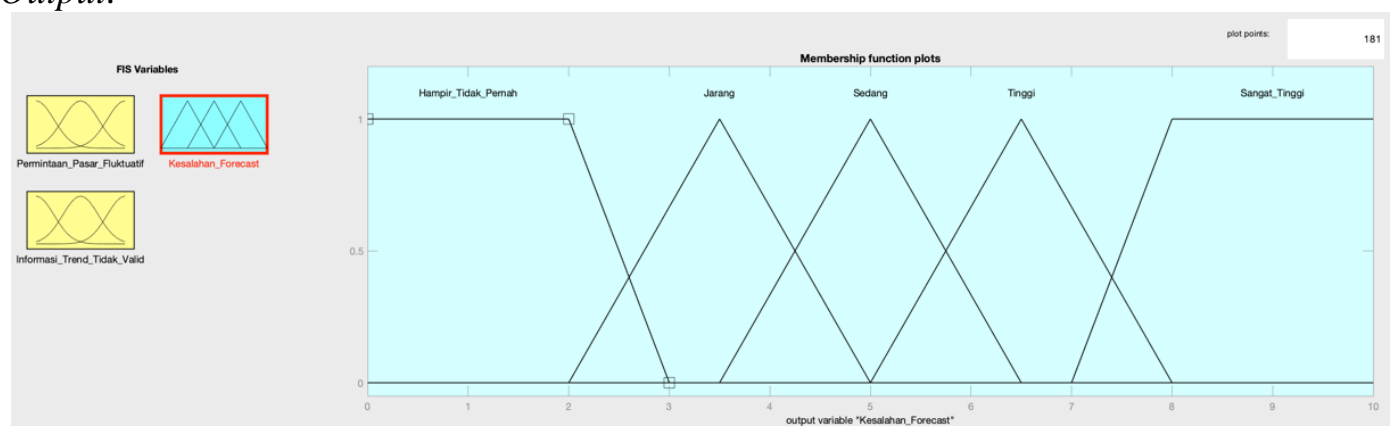

Gambar 8. Output variabel kesalahan forecast

\subsubsection{Pembentukan Aturan Logika Fuzzy}

Setelah fungsi keanggotaan telah dibentuk, langkah selanjutnya adalah pembentukan aturan logika fuzzy. Jumlah aturan logika fuzzy didapat dari jumlah membership function dipangkatkan dengan jumlah variabel sehingga terbentuk 125 aturan untuk risk event dan 25 aturan untuk risk agent seperti dibawah ini.

- Aturan logika fuzzy risk event

Berikut merupakan 1 contoh aturan dari 125 aturan logika fuzzy untuk risk event yang telah ditentukan bersama dengan perusahaan adalah sebagai berikut:

If (Perubahan Jadwal Produksi is Sangat Tidak Berpengaruh) and (Kapasitas Produksi Terganggu is Sangat Tidak Berpengaruh) and (Kerugian Finansial is Sangat Tidak Berpengaruh) then (Pesanan Yang Diterima Tidak Sesuai Dengan Forecast is Tidak ada Dampak)

- Aturan logika fuzzy risk agent

Berikut merupakan 1 contoh aturan dari 25 aturan logika fuzzy untuk risk agent yang telah ditentukan bersama dengan perusahaan adalah sebagai berikut:

If (Permintaan Pasar Fluktuatif is Sangat Tidak Berpengaruh) and (Informasi Perkembangan Trend Dari Konsumen Tidak Valid is Sangat Tidak Berpengaruh) then (Kesalahan Forecast Dari Pembeli is Hampir Tidak Pernah)

\subsubsection{Penegasan (defuzzyfikasi)}

Setelah aturan fuzzy telah ditetapkan, langkah selanjutnya adalah penegasan (defuzzyfikasi). Penegasan dilakukan dengan metode centroid dimana penetapan nilai crisp dengan cara mengambil titik pusat daerah. Penegasan fuzzy dengan menggunakan metode centroid dengan bantuan software MATLAB 2019 dapat dilihat pada gambar 9 dan 10. Hasil dari penegasan inilah yang menjadi input dari nilai severity dan occurrence yang dapat dilihat pada tabel 9 dan 10. 


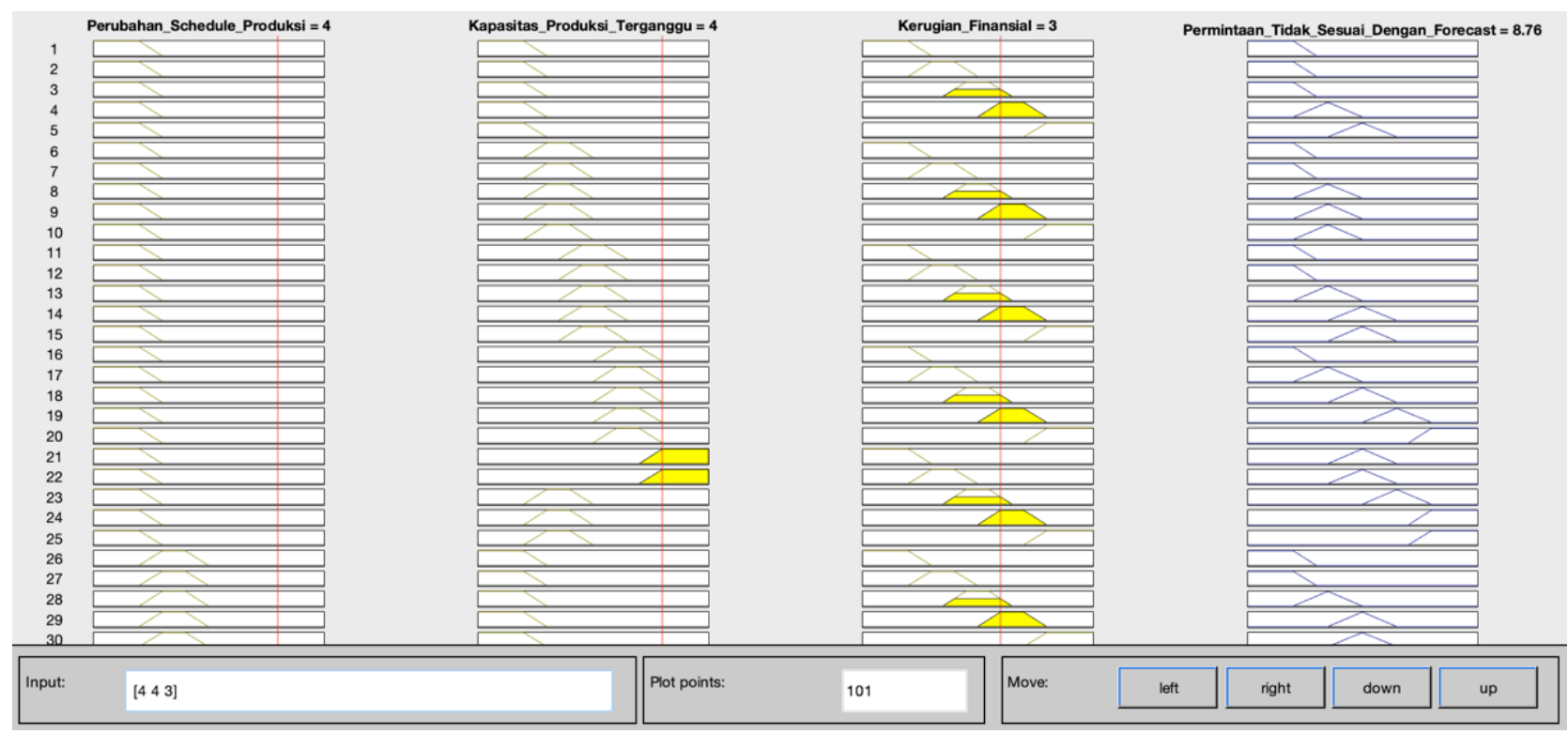

Gambar 9. Penegasan fuzzy risk event dengan metode centroid

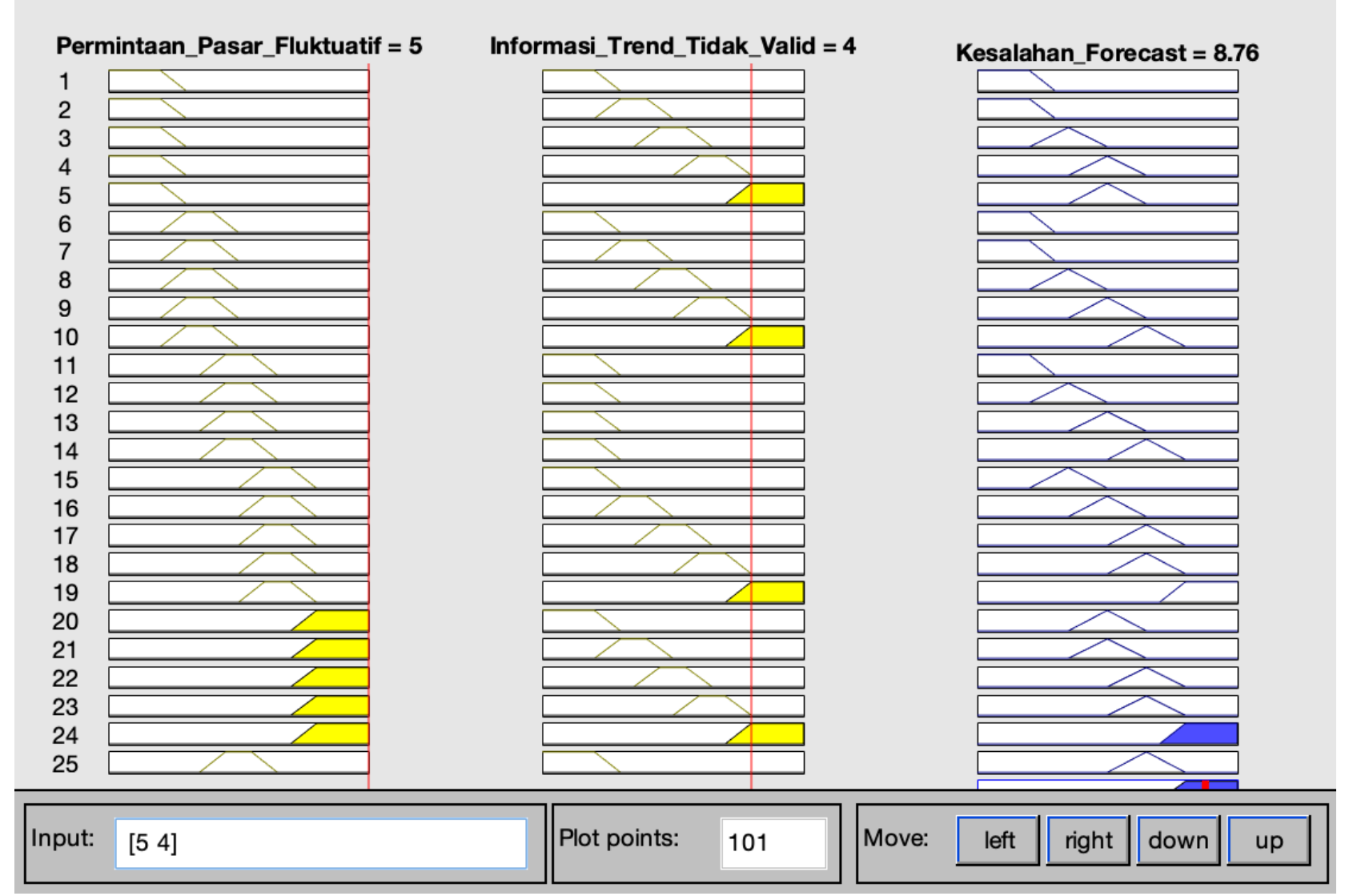

Gambar 10. Penegasan fuzzy risk agent dengan metode centroid

\subsubsection{Pengisian Skor Severity dan Occurrence}

Setelah melakukan proses penegasan, langkah terakhir yang dilakukan adalah pengisian skor severity dan occurrence ke dalam tabel risk event dan risk agent. Skor dari severity dan occurrence didapat dari hasil defuzzyfikasi. Contoh untuk pengisian skor severity dengan kode E1, input kesatu memiliki nilai 4 , input kedua memiliki nilai 4, input ketiga memiliki nilai 3 dan output yang dihasilkan adalah 8,76 pada Tabel 9. Contoh untuk pengisian skor occurrence degan kode A1, 
input kesatu memiliki nilai 5, input kedua memiliki nilai 4 dan output yang dihasilkan adalah 8,76 pada Tabel 10.

Tabel 9. Hasil pengukuran Risk Event dan Skor Fuzzy

\begin{tabular}{|c|c|c|c|}
\hline Kode & Risk Event & $\begin{array}{l}\text { Tahapan } \\
\text { SCOR }\end{array}$ & Severity \\
\hline E1 & Pesanan yang diterima tidak sesuai dengan forecast & Plan & 8,76 \\
\hline E2 & $\begin{array}{l}\text { Terjadi kekurangan material yang disebabkan oleh } \\
\text { kesalahan perhitungan }\end{array}$ & Plan & 8,1 \\
\hline E3 & Pengadaan material terlambat & Plan & 8,76 \\
\hline E4 & $\begin{array}{l}\begin{array}{l}\text { Pengiriman material } \\
\text { keterlambatan }\end{array} \\
\end{array}$ & Source & 8,1 \\
\hline E5 & Raw material yang diterima tidak sesuai dengan spesifikasi & Source & 8,76 \\
\hline E6 & Keterlambatan memproduksi barang dari jadwal & Make & 8,76 \\
\hline E7 & Target produksi tidak tercapai & Make & 8,76 \\
\hline E8 & Keterlambatan pengiriman barang jadi ke customer & Delivery & 4,81 \\
\hline E9 & Barang jadi yang dikirim tidak sesuai dengan spesifikasi & Derlivery & 8,76 \\
\hline E10 & Retur produk cacat dari customer & Return & 5,75 \\
\hline E11 & Retur bahan baku ke supplier & Return & 5,88 \\
\hline
\end{tabular}

Tabel 10. Hasil pengukuran Risk Agent dan Skor Fuzzy

\begin{tabular}{|l|l|l|}
\hline Kode & Risk Agent & Occurrence \\
\hline A1 & Kesalahan forecast dari customer & 8,76 \\
\hline A2 & Purchase order secara mendadak oleh customer & 8,76 \\
\hline A3 & Komunikasi kurang baik dengan supplier & 8,76 \\
\hline A4 & Kapasitas produksi tidak memadai & 8,76 \\
\hline A5 & Terlambat dalam memenuhi target produksi & 8,76 \\
\hline A6 & Terjadi kerusakan atau kendala pada mesin & 6,5 \\
\hline A7 & Kinerja buruh tidak maksimal & 8,76 \\
\hline A8 & Terjadi cacat produk pada hasil produksi & 8,76 \\
\hline A9 & Human error & 8,76 \\
\hline
\end{tabular}

\subsection{Tabel HOR fase pertama}

Tabel House of Risk fase pertama merupakan tahapan akhir dalam pengidentifikasian risiko. Tabel ini memperlihatkan nilai severity dan occurrence serta nilai korelasi antara risk event dan risk agent yang didapatkan melalui hasil wawancara serta brainstorming dengan eksekutif perusahaan dan menyajikan hasil perhitungan ARP serta ranking dari potensi sumber risiko yang selanjutnya diprioritaskan untuk dilakukan aksi mitigasi terlebih dahulu. 
Tabel 11. HOR fase pertama

\begin{tabular}{|c|c|c|c|c|c|c|c|c|c|c|c|}
\hline \multirow{2}{*}{$\begin{array}{c}\text { Risk } \\
\text { Event } \\
\text { (Ei) }\end{array}$} & \multicolumn{10}{|c|}{ Risk Agent (Ai) } & $\begin{array}{c}\text { Sever } \\
\text { ity }\end{array}$ \\
\hline & A1 & $\mathrm{A} 2$ & $\mathrm{~A} 3$ & $\mathrm{~A} 4$ & $\mathrm{~A} 5$ & $\mathrm{~A} 6$ & $\mathrm{~A} 7$ & $\mathrm{~A} 8$ & $\mathrm{~A} 9$ & A10 & \\
\hline E1 & 9 & & & 9 & & & & & & & 8,76 \\
\hline $\mathrm{E} 2$ & & & 1 & & 3 & & & & 3 & & 8,1 \\
\hline E3 & & & 3 & & 3 & & & & & & 8,76 \\
\hline E4 & & 3 & 9 & 1 & 3 & & & & & & 8,1 \\
\hline E5 & & & & & 1 & & 9 & & & & 8,76 \\
\hline E6 & 3 & & 1 & 3 & 9 & 9 & 9 & & & & 8,76 \\
\hline E7 & 3 & 3 & 1 & 3 & 3 & 9 & 3 & & 3 & & 8,76 \\
\hline E8 & 3 & & 1 & & & & & & 3 & 3 & 4,81 \\
\hline E9 & & & & & & & & 9 & 3 & 9 & 8,76 \\
\hline E10 & & 3 & & & & & & 9 & & & 5,75 \\
\hline E11 & & & & & & & & & & & 5,88 \\
\hline $\begin{array}{c}\text { Occurr } \\
\text { ence }\end{array}$ & 8,76 & 8,76 & 8,76 & 8,76 & 8,76 & 6,5 & 8,76 & 8,76 & 8,76 & 6,5 & \\
\hline & 1277,4 & 594,1 & 1135,3 & 1222 & 1653,5 & 1024 & 1611,4 & 1143,9 & 799,7 & 606, & \\
ARP & 708 & 908 & 836 &, 02 & 376 &, 92 & 896 & 684 & 004 & 255 & \\
\hline Rank & 3 & 10 & 6 & 4 & 1 & 7 & 2 & 5 & 8 & 9 & \\
\hline
\end{tabular}

Setelah tabel House of Risk fase 1 diisi, nilai ARP dapat dihitung dan dapat dibuat ranking dari risk agent.

Tabel 12. Ranking Risk Agent

\begin{tabular}{|c|c|c|c|c|c|}
\hline Rank & Kode & Risk Agent & ARP & Kumulatif & $\begin{array}{l}\text { Bobot } \\
\text { Kumulatif }\end{array}$ \\
\hline 1 & A5 & $\begin{array}{l}\text { Terlambat dalam } \\
\text { memenuhi target } \\
\text { produksi }\end{array}$ & 1653,538 & 1653,538 & $15 \%$ \\
\hline 2 & A7 & $\begin{array}{l}\text { Kinerja buruh tidak } \\
\text { maksimal }\end{array}$ & 1611,49 & 3265,028 & $29 \%$ \\
\hline 3 & A1 & $\begin{array}{l}\text { Kesalahan forecast dari } \\
\text { customer }\end{array}$ & 1277,471 & 4542,499 & $41 \%$ \\
\hline 4 & A4 & $\begin{array}{l}\text { Kapasitas produksi } \\
\text { tidak memadai }\end{array}$ & 1222,02 & 5764,519 & $52 \%$ \\
\hline 5 & A8 & $\begin{array}{l}\text { Terjadi cacat produk } \\
\text { pada hasil produksi }\end{array}$ & 1143,968 & 6908,487 & $62 \%$ \\
\hline 6 & A3 & $\begin{array}{l}\text { Komunikasi kurang } \\
\text { baik dengan supplier }\end{array}$ & 1135,384 & 8043,871 & $73 \%$ \\
\hline 7 & A6 & $\begin{array}{l}\text { Terjadi kerusakan atau } \\
\text { kendala pada mesin }\end{array}$ & 1024,92 & 9068,791 & $82 \%$ \\
\hline 8 & A9 & Human error & 799,7004 & 9868,4914 & $89 \%$ \\
\hline 9 & A10 & $\begin{array}{l}\text { Kesalahan pada divisi } \\
\text { pengiriman }\end{array}$ & 606,255 & 10474,7464 & $95 \%$ \\
\hline 10 & $\mathrm{~A} 2$ & $\begin{array}{l}\text { Purchase order secara } \\
\text { mendadak oleh } \\
\text { customer }\end{array}$ & 594,1908 & 11068,9372 & $100 \%$ \\
\hline
\end{tabular}

Dari tabel diatas, dapat dilihat 10 sumber risiko yang telah diurutkan berdasarkan nilai ARP. Perusahaan meminta agar 5 sumber risiko utama yang diprioritaskan untuk dilakukan perancangan strategi mitigasi risiko. Sehingga kelima sumber risiko yang dipakai untuk menjadi dasar perancangan strategi mitigasi risiko adalah A5, A7, A1, A4 dan A8.

\subsection{Perancangan Strategi Mitigasi Risiko}

Setelah mengetahui sumber risiko yang akan dipakai menjadi dasar perancangan strategi mitigasi risiko, tahap selanjutnya akan dilakukan brainstorming dengan eksekutif perusahaan untuk 
merancang strategi mitigasi dalam mengatasi sumber risiko. Tabel 13 merupakan perancangan strategi mitigasi risiko untuk melakukan pencegahan resiko. Strategi ini merupakan hasil diskusi dengan eksekutif perusahaan.

Tabel 13. Perancangan Strategi Mitigasi

\begin{tabular}{|l|l|}
\hline Kode & \multicolumn{1}{c|}{ Tindak Pencegahan } \\
\hline PA1 & Mengoptimalkan kapasitas produksi \\
\hline PA2 & Memberikan pelatihan kerja secara lebih mendalam \\
\hline PA3 & Menambah tenaga kerja \\
\hline PA4 & Memperbaiki Instruksi Kerja (IK) agar lebih jelas dimengerti oleh para buruh \\
\hline PA5 & Melakukan manajemen safety stock \\
\hline PA6 & Menganalisa perkembangan pasar \\
\hline PA7 & Menambah jumlah mesin \\
\hline
\end{tabular}

\subsection{House of Risk Fase 2}

Setelah menyelesaikan perancangan strategi mitigasi risiko, tahap selanjutnya yang akan dilakukan adalah HOR fase 2.

Tabel 14. House of Risk Fase 2

\begin{tabular}{|c|c|c|c|c|c|c|c|c|}
\hline \multirow{2}{*}{$\begin{array}{l}\text { To be treated risk } \\
\text { agent }(\mathrm{Aj})\end{array}$} & \multicolumn{7}{|c|}{ Preventive Action (PAk) } & \multirow{2}{*}{$\begin{array}{l}\text { Aggregate Risk } \\
\text { Potential (ARP) }\end{array}$} \\
\hline & PA1 & PA2 & PA3 & PA4 & PA5 & PA6 & PA7 & \\
\hline A5 & 9 & 3 & 3 & & & & & 1653,538 \\
\hline A7 & & 9 & & 9 & & & & 1611,49 \\
\hline A1 & 3 & & & & 9 & 9 & & 1277,471 \\
\hline A4 & 3 & & 3 & & 3 & & 9 & 1222,02 \\
\hline A8 & & 9 & & 9 & & & & 1143,968 \\
\hline $\begin{array}{l}\text { Total effectiveness } \\
\text { of action } \mathrm{k}\end{array}$ & $\begin{array}{r}22380 \\
315 \\
\end{array}$ & $\begin{array}{r}15256 \\
, 326 \\
\end{array}$ & $\begin{array}{r}8626 \\
674 \\
\end{array}$ & $\begin{array}{r}10295 \\
, 712 \\
\end{array}$ & $\begin{array}{r}15163 \\
, 299 \\
\end{array}$ & $\begin{array}{r}11497 \\
239 \\
\end{array}$ & $\begin{array}{r}1099 \\
8,18 \\
\end{array}$ & \\
\hline $\begin{array}{l}\text { Degree of difficulty } \\
\text { performing } \mathrm{k}\end{array}$ & 4 & 4 & 3 & 3 & 3 & 4 & 4 & \\
\hline $\begin{array}{l}\text { Effectiveness to } \\
\text { difficulty ratio } \mathrm{k}\end{array}$ & $\begin{array}{r}5595,0 \\
7875 \\
\end{array}$ & $\begin{array}{r}3814, \\
0815 \\
\end{array}$ & $\begin{array}{r}2875 \\
558 \\
\end{array}$ & $\begin{array}{r}3431 \\
904 \\
\end{array}$ & $\begin{array}{r}5054 \\
433 \\
\end{array}$ & $\begin{array}{r}2874,3 \\
0975 \\
\end{array}$ & $\begin{array}{r}2749 \\
545 \\
\end{array}$ & \\
\hline Rank of priority & 1 & 3 & 5 & 4 & 2 & 6 & 7 & \\
\hline \multirow{2}{*}{$\begin{array}{c}\text { To be treated risk } \\
\text { agent }(\mathrm{Aj})\end{array}$} & \multicolumn{7}{|c|}{ Preventive Action (PAk) } & Aggregate Risk \\
\hline & PA1 & PA2 & PA3 & PA4 & PA5 & PA6 & PA7 & Potential (ARP) \\
\hline A5 & 9 & 3 & 3 & & & & & 1653,538 \\
\hline A7 & & 9 & & 9 & & & & 1611,49 \\
\hline A1 & 3 & & & & 9 & 9 & & 1277,471 \\
\hline A4 & 3 & & 3 & & 3 & & 9 & 1222,02 \\
\hline A8 & & 9 & & 9 & & & & 1143,968 \\
\hline $\begin{array}{l}\text { Total effectiveness } \\
\text { of action } \mathrm{k}\end{array}$ & $\begin{array}{r}22380 \\
315 \\
\end{array}$ & $\begin{array}{r}15256 \\
, 326 \\
\end{array}$ & $\begin{array}{r}8626, \\
674 \\
\end{array}$ & $\begin{array}{r}10295 \\
, 712 \\
\end{array}$ & $\begin{array}{r}15163 \\
, 299 \\
\end{array}$ & $\begin{array}{r}11497 \\
239 \\
\end{array}$ & $\begin{array}{r}1099 \\
8,18 \\
\end{array}$ & \\
\hline $\begin{array}{l}\text { Degree of difficulty } \\
\text { performing } \mathrm{k}\end{array}$ & 4 & 4 & 3 & 3 & 3 & 4 & 4 & \\
\hline $\begin{array}{l}\text { Effectiveness to } \\
\text { difficulty ratio } \mathrm{k}\end{array}$ & $\begin{array}{r}5595,0 \\
7875 \\
\end{array}$ & $\begin{array}{r}3814, \\
0815 \\
\end{array}$ & $\begin{array}{r}2875 \\
558 \\
\end{array}$ & $\begin{array}{r}3431 \\
904 \\
\end{array}$ & $\begin{array}{r}5054 \\
433 \\
\end{array}$ & $\begin{array}{r}2874,3 \\
0975 \\
\end{array}$ & $\begin{array}{r}2749 \\
545 \\
\end{array}$ & \\
\hline Rank of priority & 1 & 3 & 5 & 4 & 2 & 6 & 7 & \\
\hline
\end{tabular}


HOR fase 2 menunjukan nilai dari Total Effectiveness of action $k$ untuk mengurangi probabilitas kemunculan risk agent dan perhitungan prioritas dari Preventive Action. Dapat dilihat dari Tabel 14 bahwa urutan prioritas adalah PA1, PA5, PA2, PA4, PA3, PA6, PA7 atau dapat dikatakan prioritas berdasarkan yang paling penting adalah mengoptimalkan kapasitas produksi, melakukan manajemen safety stock, memberikan pelatihan kerja secara lebih mendalam, memperbaiki Instruksi Kerja (IK) agar lebih jelas dimengerti oleh para buruh, menambah tenaga kerja, menganalisa perkembangan pasar, dan menambah jumlah mesin sebagai langkah strategi terakhir.

\section{Kesimpulan dan Saran}

Hasil dari penelitian ini menunjukan bahwa setiap perusahaan memiliki permasalahan yang khas dan berbeda sehingga penggunaan metode ini akan menghasilkan hasil yang berbeda pula. Metode ini dapat diadopsi oleh pengambil kebijakan yang ingin menggunakan cara yang sistematis dalam menganalisa potensi risiko dalam rantai pasok di perusahaannya. Kesimpulan yang dapat diambil dari studi kasus ini bagi PT X adalah terdapat 10 sumber risiko yang terdapat di sepanjang aktivitas rantai pasok PT X. Prioritas aksi mitigasi dilakukan pada 5 sumber risiko dominan. Kelima sumber risiko tersebut yaitu: terlambat dalam memenuhi target produksi, kinerja buruh tidak maksimal, kesalahan forecast dari customer, kapasitas produksi tidak memadai dan terjadi cacat produk pada hasil produksi. Terdapat 7 strategi mitigasi risiko yang diprioritaskan untuk mengatasi kelima sumber risiko yang terdapat di PT X.

Saran bagi PT X adalah penerapan aksi mitagasi dan strategi dari penelitian ini. Selain itu belum adanya divisi rantai pasok pada perusahaan, sehingga disarankan untuk dibuat divisi tersebut. Hasil prioritas strategi, ada penambahan jumlah tenaga kerja dan penambahan jumlah mesin. Penelitian selanjutnya dapat melakukan perhitungan menggunakan analisis ekonomi teknik untuk perhitungan investasi atau simulasi untuk mengetahui jumlah optimal penambahan yang harus dilakukan.

\section{Daftar Pustaka}

Heizer, J dan Render,B. (2014), Manajemen Operasi: Manajemen Keberlangsungan dan Rantai Pasokan, Salemba Empat, Jakarta.

Kusumadewi, S dan Purnomo,H. (2010), Aplikasi Fuzzy Logic. Graham Ilmu, Yogyakarta.

Ma, H. dan Wong, W. (2018),"A fuzzy-based House of Risk assessment method for manufacturers in global supply chains", Industrial Management \& Data Systems, Vol. 118, No. 7, pp. 1463-1476. https://doi.org/10.1108/IMDS-10-2017-0467.

Pujawan, I.N. dan Er, M. (2017), Supply Chain Management Edisi 3, Andi Offset, Yogyakarta.

Pujawan, I.N. dan Er, M. (2010), Supply Chain Management Edisi ke-2, Guna Widya, Surabaya.

Pujawan, I.N dan Geraldin, L.H. (2009),"House of risk: a model for proactive supply chain risk management", Business Process Management Journal, Vol. 15, No. 6, pp 953-967.

Simchi-Levi,D, Kaminsky, P. dan Simchi-Levi, E. (2010),"Designing and Managing the Supply Chain: Concepts, Strategies and Case Studies", McGraw-Hill International Edition, Singapore. 